\title{
Anna Markwart, Bogactwo uczuć moralnych. Jednostka i społeczeństwo we wzajemnych oddziaływaniach w perspektywie filozofii Adama Smitha, Wydawnictwo Naukowe UMK, Toruń 2017, ss. 400
}

DOI: http://dx.doi.org/10.12775/RF.2017.042

W dobie agresywnego kapitalizmu i czasach kultu jednostki ekonomiści rozważają procesy rynkowe i mechanizmy przemian społecznych, zapominając o człowieku i aksjologicznym wymiarze jego życia. We współczesnym dyskursie na temat gospodarki i społeczeństwa kwestia moralności i problematyka dotycząca wartości została zepchnięta na margines, przestała odgrywać znaczącą rolę w przestrzeni publicznej. A przecież $\mathrm{w}$ centrum wszelkich procesów społecznych znajduje się człowiek, ze swymi uczuciami i potrzebami, ze swoim doświadczeniem życiowym, człowiek, który funkcjonuje w sieci wzajemnych powiązań między gospodarka, społeczeństwem i moralnością. Książka Anny Markwart zatytułowana Bogactwo uczuć moralnych ${ }^{1}$, poświęcona klasykowi nowożytnej ekonomii Adamowi Smithowi, właśnie o tym przypomina. Teoria ekonomiczna, z której Smith zasłynął, stanowi bowiem tylko jeden aspekt jego myśli, drugim jest nieco zepchnięta w cień tworzona przezeń teoria moralna. Omawiana monografia przypomina o tej właśnie, niekiedy niedocenianej części dorobku szkockiego filozofa; stanowi przy tym nie tylko rzetelną pracę badawcza, która uzupełnia dotychczasowe braki polskojęzycznej literatury przedmiotowej2, ale także w bardzo ciekawym świetle przedstawia zagadnienia społeczno-gospodarcze.

1 A. Markwart, Bogactwo uczuć moralnych. Jednostka i społeczeństwo we wzajemnych oddziaływaniach w perspektywie filozofii Adama Smitha, WN UMK, Torun 2017.

2 Z polskojęzycznej literatury poświęconej filozofii Smitha na uwagę zasługują następujące prace: J. Chodorowski, Adam Smith (1723-1790). Życie i dzieło autora "Badań nad natura i przyczynami bogactwa narodów", Wydawnictwo Uwr., Wrocław 2002; S. Zabieglik, Smith, Wiedza Powszechna, Warszawa 2003 (i jest to najlepsza monografia na polskim rynku wydawniczym); M. Cichorzewska, Moralność $i$ społeczeństwo w myśli Adama Smitha, Wydawnictwa Uczelniane, Lublin 2008 oraz W. Piątkowski, Adam Smith. Ekonomia polityczna, Wydawnictwo UŁ, Łódź 2013. 
Recenzowana rozprawa składa się ze wstępu, pięciu rozdziałów, z których każdy poświęcony jest odrębnemu aspektowi myśli szkockiego filozofa, wniosków końcowych, aneksu i bibliografii. Uzupełniający całość aneks zawiera krótką biografię Smitha, charakterystykę myśli filozoficznej szkockiego oświecenia, a także zwięzłe omówienie poglądów estetycznych i etycznych Shaftesbury'ego i Francisa Hutchesona oraz filozofii Davida Hume'a. Zestawienie to służy ukazaniu kontekstu intelektualnego myśli autora Bogactwa narodów $w^{3}$ i porównaniu różnych rozstrzygnięć poszczególnych problemów.

W rozdziale pierwszym Autorka omawia szczegółowo podstawowe pojęcia teorii moralnej wyłożone w Teorii uczuć moralnych Smitha: sympatii, wyobraźni i bezstronnego obserwatora. Sympatia (sympathy), zwana również współodczuwaniem czy oddźwiękiem uczuciowym ${ }^{4}$, jest w myśli szkockiego filozofa terminem kluczowym. Fakt ten odzwierciedlają szczegółowe rozważania, jakie poświęca jej Autorka. Wyjaśnia w nich, że jest to umiejętność wczucia się w stan emocjonalny drugiej osoby i postawienia się na jej miejscu, jednocześnie podkreśla też, że nie należy sympatii mylić z empatią ani życzliwością gdyż w opisywanym przez filozofa mechanizmie wydawania przez ludzi ocen i sądów moralnych nie chodzi o proste zarażanie się emocjami od innych ani o zwykłą przychylność wobec drugiej osoby. Do pojęcia sympatii Autorka odwołuje się wielokrotnie, każdorazowo wskazuje przy tym jej szczególną rolę w obrębie poglądów Adama Smitha. Uważał on, że zdolność ta ma wielkie znaczenie dla kształtowania i wydawania sądów moralnych i estetycznych, ale jednocześnie wypełnia bardziej fundamentalne zadanie, jakim jest umożliwienie zadzierzgnięcia więzi społecznych. W obu przypadkach nieodzowne jest wsparcie ze strony wyobraźni, dzięki której jesteśmy w stanie ocenić, jak zachowalibyśmy się w sytuacji, w którą zaangażowany jest ktoś inny. Autorka zaznacza, że obydwie te zdolności współdziałają ze sobą przy ocenie ludzkiego postępowania. Jednak ocena moralna możliwa jest dopiero po zajęciu postawy bezstronnego obserwatora, która pozwala na abstrahowanie od własnej sytuacji oraz określenie powszechnie obowiązujących w społeczeństwie norm zachowania.

W rozdziale kolejnym Autorka rekonstruuje analizy szkockiego filozofa dotyczące roli zmysłów zewnętrznych całości doświadczenia,

3 A. Smith, Badania nad natura i przyczynami bogactwa narodów, przeł. S. Wolff et al., PWN, Warszawa 2007.

4 W polskiej literaturze przedmiotowej ze względu choćby na utrwalający pewną tradycję przekład A Treatise of Human Nature Hume'a pióra Znamierowskiego przyjmuje się, że termin sympathy najdokładniej oddaje polski oddźwięk uczuciowy. Nie ma wówczas mowy o pomyłce z sympatią rozumianą jako współczucie, a takie właśnie uproszczenie w znacznej mierze wypaczyłoby myśl Smitha. 
zwracając przy tym uwagę na jego inspiracje myślą Johna Locke’a i George'a Berkeleya. Opisuje też znany z Locke'owskich Rozwazań dotyczacych rozumu ludzkiego problem Molyneux i przybliża różnice w ujmowaniu organów zmysłowych, ich funkcjonowania i roli w procesach poznawczych przez najważniejszych filozofów epoki. W tej części monografii omówione zostały także prace filozofa poświęcone historii nauk (Historia astronomii, Historia fizyki i Historia logiki) i wskazuje na zawarte w nich odniesienia do filozofii Hume’a. W części rozdziału poświęconej powstawaniu i rozwojowi języków analizuje treści zawarte w eseju Considerations Concerning the First Formation of Language. Również i w tym zakresie myśl Smitha zakorzenia się w dorobku innych myślicieli, które Autorka znakomicie przybliża. Należy wymienić tu przywoływane w pracy analizy Locke'a, G. W. Leibniza, E. B. Condillaca czy J. J. Rousseau. Dzięki temu zabiegowi możemy zapoznać się z szerszym kontekstem ówczesnych sporów wokół omawianej tematyki, natomiast czytelnik nie posiadający gruntownej wiedzy z zakresu historii filozofii zyskuje możliwość pełniejszego zrozumienia myśli szkockiego filozofa.

W rozdziale trzecim Markwart skupia się na zagadnieniach estetycznych. Poglądy Smitha $w$ tej dziedzinie są rozproszone $w$ jego pomniejszych pracach. Autorka dokonuje ich syntetycznego omówienia, umieszczając je w kontekście całokształtu poglądów Smitha dotyczących społecznego charakteru człowieka i wzajemnych oddziaływań społeczeństwa i jednostki. Zdaniem autora Teorii uczuć moralnych za kształtowanie kanonów piękna oraz mody odpowiedzialne jest uczucie podziwu dla bogatych i możnych, które jak podkreśla badaczka, jest także podstawą porządku społecznego oraz dążenia do dobrobytu i postępu. W tym miejscu Markwart wskazuje na związek myśli estetycznej i etycznej, który na Wyspach podkreślali już wcześniej Shaftesbury i Hutcheson. Fakt, że w tym przypadku nie mamy do czynienia z oryginalną koncepcją a raczej poglądami dość typowymi dla epoki, sprawia, że autorka nie przedstawiła szczegółowych odniesień teorii Smitha do koncepcji poprzedników. Większa jej część to w zasadzie powtórzenie spostrzeżeń na temat piękna zawartych w Traktacie o naturze ludzkiej Hume'a, jak dość eklektyczne odwołania do poglądów innych ówczesnych teoretyków sztuki. Pojmowanie piękna jako użyteczności czy też stosowności, a nawet funkcjonalności i dostosowania było wówczas dość powszechnym zjawiskiem. Cenne natomiast są rozważania Smitha poświęcone muzyce i tańcowi, w których to artyści starają się wyrazić uczucia i silne emocje ${ }^{5}$. Dzięki temu, że jedni dzielą się emocjami z innymi, budowane są międzyludzkie relacje, a także tworzy się więź spo-

5 Osiemnastowieczna estetyka brytyjska niewiele miejsca poświęciła temu zagadnieniu, stąd ważność głosu Smitha w tej kwestii. Nie należy jednakże przeceniać także tutaj oryginalności jego poglądów. W gruncie rzeczy przypisywanie muzyce, 
łeczna i moralna. Warto podkreślić, że autorka w tej części recenzowanej pracy zwraca uwagę na kwestie, które przez innych badaczy poruszane są rzadko, co może dziwić, gdyż niektóre z nich, jak na przykład rozważania o modzie, są zadziwiająco aktualne także dzisiaj.

W rozdziale czwartym badaczka przybliża czytelnikowi teorię ekonomiczną Smitha wyłożoną w Badaniach nad natura i przyczynami bogactwa narodów. W rzetelny sposób przedstawia jego koncepcję i zwraca uwagę na częste błędy w jej interpretacjach i rekonstrukcjach. Zdaniem autorki niesłusznie używa się $\mathrm{w}$ odniesieniu do filozofii Szkota takich pojęć jak „niewidzialna ręka rynku” czy "homo oeconomicus”, a w wielu opracowaniach pomija się społeczny charakter teorii ekonomicznej myśliciela. W moim odczuciu rozdział ten, pomimo że merytorycznie bardzo istotny, stanowi nieco słabszą część książki. Odbiega stylem od pozostałych partii monografii, jako jedyny pisany jest $\mathrm{w}$ formie bezosobowej. Praktycznie nie zawiera zdań pisanych w pierwszej osobie, wyrażających osobisty stosunek autorki do przedstawianych treści i prezentujących zajmowane przez nią stanowisko. To właśnie one wcześniej sprawiały, że myśl szkockiego filozofa stawała się bliska czytelnikowi. Zapewne wynika to z odmiennego charakteru myśli wyrażonych w Bogactwie narodów, wydaje się jednak, że podstawy teorii ekonomicznej Smitha mogłyby zostać przekazane czytelnikowi w inny sposób, być może wplecione w treść kolejnego rozdziału, którego lektura przywróciła mi przyjemność obcowania z myślą Smitha. Z drugiej jednak strony, paradoksalnie, to właśnie zwrócenie uwagi na problematykę moralną pozwala ujrzeć Smitha jako filozofa społecznego, a nie tylko teoretyka ekonomii, zatwardziałego rynkowego liberała, z którym to obrazem jest zazwyczaj kojarzony.

Rozdział ostatni stanowi zwieńczenie wcześniejszych rozważań poświęconych analizie myśli szkockiego filozofa. Autorka po raz kolejny kładzie w nim nacisk na społeczny charakter jego poglądów, określa pozycję jednostki w społeczeństwie i opisuje wzajemne powiązania i zwyczaje, w obrębie których kształtowane są normy ogólne. Wchodzi także w polemikę z autorami poruszającymi tzw. Adam Smith Problem, czyli kwestie rzekomego braku spójności pomiędzy poglądami filozofa zawartymi w Teorii uczuć moralnych i Bogactwie narodów. Zaznacza, że aby rozstrzygnać ów problem, nie wystarczy skupić się jedynie na dwóch największych dziełach Smitha. Porusza zagadnienie niewłaściwego rozumienia pojęcia interesu własnego w jego filozofii, które często jest nieprawidłowo interpretowane i mylnie utożsamiane $\mathrm{z}$ egoizmem. Dzięki temu możemy zapoznać się z wieloletnią dyskusją jaka toczy się wokół spuścizny filozoficznej Adama Smitha i poznać różne argumen-

tańcowi i śpiewowi własności katarktycznych i wychowawczych występowało już w antycznej Grecji. 
tacje, $\mathrm{w}$ tym również te niezgodne ze stanowiskiem przyjętym przez Markwart. Autorka odnosi się do nich krytycznie i broni tezy, zgodnie z którą myśl Adama Smitha jest spójna, a kluczem do zrozumienia owej spójności jest pojmowanie człowieka jako jednostki, która ma wpływ na normy moralne, społeczeństwo i gospodarkę, i odwrotnie, ona sama jest przez nie kształtowana, a sam ten proces ma charakter dynamiczny. Błędem jest oddzielne traktowanie poruszanych przezeń kwestii etycznych, estetycznych i ekonomicznych. Różne aspekty myśli filozoficznej autora Bogactwa narodów należy traktować jako elementy spójnego światopoglądu. Takie właśnie systemowe spojrzenie zarówno na myśl filozoficzną Adama Smitha, jak i na społeczeństwo, gospodarkę i moralność w ujęciu ogólnym, jest możliwe, czego dowodzi lektura książki Markwart.

Warto zaznaczyć, że książka Bogactwo uczuć moralnych doskonale wpisuje się we współczesne badania nad spuścizną szkockiego myśliciela, odnosi się ona bowiem do najnowszych opracowań i dyskusji, jakie dziś toczą się na całym świecie. Wypełnia ona zarazem lukę w polskojęzycznej literaturze przedmiotu i stanowi ważny głos w sprawie spójności poglądów Smitha. Wspomniany wcześniej aneks doskonale ją uzupełnia, choć wyraźnie brak w nim pewnego przenikającego całą monografię socjologizującego stylu czy nawet żargonu. Nie jest to zresztą żaden zarzut, gdyż ów specyficzny styl pisania wynika z samego charakteru rozważań Szkota, używanych przezeń terminów, opisywanych relacji i pewnej powierzchowności jego uwag, będącej często skutkiem niesamodzielności autora i przejmowania przez niego rozstrzygnięć dotyczących bardziej fundamentalnych kwestii, jak choćby tego, czym jest i jak działa wyobraźnia, od myślicieli takich jak Pascal czy Hume. Na szczęście Markwart dokładnie tropi wszelkie zapożyczenia w poglądach Smitha, wskazuje je i omawia ich znaczenie dla jego myśli. Należy raz jeszcze podkreślić, że dzięki temu, iż po raz pierwszy tak wnikliwie opracowana została koncepcja moralna Smitha, polski czytelnik może ujrzeć w jego osobie nie tylko ekonomistę, postulującego kierowanie się twardym rachunkiem zysków i strat oraz własnym interesem jednostek, ale też wrażliwego moralistę, zwracającego uwagę na uczuciowe więzi łączące ludzi. Zgodnie z przedstawianą w monografii interpretacją oba aspekty jego twórczości wzajemnie się uzupełniają. Dzięki takiemu omówieniu otrzymujemy zniuansowany portret klasyka myśli oświeceniowej, bogaty w konteksty, napisany w sposób spójny i niemal cały czas zajmujący. W ten sposób należy rekonstruować poglądy wielkich myślicieli. 